\title{
"SUOMALAISTUTKIJAT TEKIVÄT MULLISTAVAN HAVAINNON" - ANALYYSI VUODEN 2004 TERVEYSAIHEISISTA TIEDOTTEISTA
}

\begin{abstract}
Tässä tutkimuksessa analysoidaan kahden suomalaisen lä̈ketieteen toimittajan vuoden 2004 aikana saamat sairauksien syntyä, ehkäisyä ja hoitoa koskevat lebdistötiedotteet. Tiedotteita kertyi 275 kappaletta. Artikkelissa selvitetään, mitkä tahot tuottavat tiedotteita ja mitä sairauksia niissä käsitellä̈n. Lisäksi argumentaatioanalyysillä tutkittiin, miten tiedotteissa perustellaan aibeen tärkeyttä ja tavoitellaan pääsyä mediaan. Syöpätaudit ovat selvästi suurin yksittäinen tautiryhmä, josta tiedotettiin. Seuraavaksi suurin sairausrybmä olivat sydän- ja verisuonitaudit. Tiedotteita mielenterveysongelmista oli vähän. Analyysissa havaittiin kolme yleistä argumentaatiotyyppiä: 1) tieteellinen, 2) taloudellinen ja 3) inbimillinen. Tieteellinen argumentaatio perustelee tutkimuksen merkitystä pääsyllä kansainväliseen julkaisuun. Terveyden ekonomisaatio on pä̈tynyt lehdistötiedotteisiin taloudellisena argumentaatiotyyppinä, jossa sairaudet esitetä̈n ybteiskunnalle kalliina ilmiönä. Inbimillinen argumentaatiotyyppi rakentaa sairaudesta kuvaa ubkana, jota ibmisen on vaikea tunnistaa ja vastustaa. Journalistisia käytäntöjä pyritään lehdistötiedotteissa miellyttämä̈n käyttämällä runsaasti uhan ja taistelun metaforia. Lisävakuuttavuutta argumentaatioon saadaan yleistä arvostusta nauttivan lä̈̈äriprofession edustajien kommenteilla.
\end{abstract}

Terveys on nykysuomalaisten tärkein arvo. Tampereen yliopiston tuottamassa arvopreferenssejä mittaavassa tutkimuksessa 60 prosenttia suomalaisista ilmoitti terveyden kolmen tärkeimmän arvon joukkoon (Suhonen 2007). Henkilökohtainen terveys on ohittanut takavuosien tärkeimmäksi arvoksi mielletyn rauhan. Myös hyviä ihmissuhteita arvostetaan lähes yhtä paljon kuin terveyttä. Kun välitöntä konfliktin uhkaa ei ole, on tullut tilaa henkilökohtaisemmille arvoille. Suhonen arvioi terveyden ihanteiden vahvistuneen suomalaisessa kulttuurissa ja yhteiskuntaelämässä. Tämä on näkynyt hänen mukaansa valtiovallan ja kuntien terveysvalistuksen lisääntymisenä ja toisaalta "monimuotoisen terveysviestinnän ja terveyden markkinoinnin kasvuna” (emt. 40).

Meillä ei kuitenkaan ole tarkkaa tutkimustietoa, ovatko terveysviestintä ja alaan liittyvä markkinointi todella "kasvaneet". Arkikokemuksemme kuitenkin

Tiedotustutkimus $2007: 4$ $30: 4,45-63$ 
puhuu näkemyksen puolesta. Lehtien lukijatutkimuksissa terveysaiheet ovat jo monena vuonna nousseet kärkisijoille. Levikkitutkimusten mukaan erikoislehdet ovat kasvattaneet suosiotaan, niiden joukossa terveydestä kirjoittavat aikakauslehdet. Sairaanhoitopiirit ovat alkaneet julkaista omia "suuren yleisön" lehtiään, samoin yksityiset terveysasemat ja apteekkiketjut. Kuluneen vuoden aikana on terveyttä edistetty muun muassa Helsingin Sanomien "läskikapinan" ja Yleisradion TV1:n Elämä pelissä -sarjan tahtiin.

Terveysviestintä ei ole vain terveyteen ja sairauteen keskittyvää journalismia. Tämä artikkeli piirtää yhden kuvan suomalaisesta 2000-luvun terveysviestinnästä tutkimalla terveydenhuollon ja lääketieteen piirissä toimivia tiedontuottajia sekä heidän toimittajille suunnattua viestintäänsä. Tutkimuksen aineisto koostuu kahden lääketieteen toimittajan vuoden 2004 aikana keräämistä mediatiedotteista, jotka käsittelevät sairauksien syntyä, ehkäisyä ja hoitoa. Analyysiin otettiin mukaan yhteensä 275 tiedotetta.

Ensimmäinen tutkimuskysymys liittyy tiedontuottajiin: mitkä yhteiskunnan tahot tuottavat eniten informaatiota, varakkaat lääkefirmat vai tuotteliaat yliopistot? Toinen kysymys etsii vastauksia tiedotteiden sisällöstä: mistä aiheista ja kuinka ahkerasti lääketieteen toimittajille Suomessa tiedotetaan? Onko mediatiedotteiden määrä suhteessa esimerkiksi sairauden yleisyyteen väestössä? Kiinnostavaa luonnollisesti on myös jäävätkö jotkin aiheet tai organisaatiot paitsioon.

Tiedotteen lähettäminen toimitukseen ei vielä takaa viestin pääsyä julkisuuteen. Kunelius $(1998,210)$ toteaa tiedottajien pyrkivän kääntämään yritysten ja yksityisten yhteisöjen ajatuksia julkisuuteen sopivaksi puheeksi. Kuneliuksen luonnehtima journalisti taas on "eräänlainen modernin myyntitykki, jonka kaupittelema tuote on moderni yhteiskunta ja sen näkemys maailmasta" (emt.212). Toinen tämän tutkimuksen peruskysymys liittyy tähän "puheen kääntäjän" ja "myyntitykin" pyrkimysten risteyskohtaan, jossa ratkeaa, päätyykö tiedotteen viesti mediaan. Analyysi kohdistuu kuitenkin ainoastaan tiedotteisiin, ei journalistisiin valintoihin: eli millaisin argumentaatioin tiedotteissa pyritään rakentamaan viesti sellaiseksi, että se läpäisee mahdollisimman muuttumattomana toimitusten uutiskynnyksen? Millä tavoin organisaatioiden pr-toiminta pyrkii miellyttämään vallitsevia journalistisia käytäntöjä?

Kunelius (2003, 223-234) korostaa, että uutisjournalismi usein enemmänkin toistaa muiden instituutioiden kielenkäytön tapoja kuin tuottaa omia esityksiään todellisuudesta. Siten myös journalistien käyttämien lähdeinstituutioiden luomat kuvat terveydestä ja sairaudesta muokkaavat merkittävästi tiedotusvälineitä seuraavien ihmisten käsityksiä. Näiden näkemysten pohjalta ihminen osaltaan rakentaa maailmankuvaansa sekä mielipiteitään sairaista ja terveistä ihmisistä.

\section{JOURNALISTISTEN KÄYTÄNTÖJEN MIELLYTTÄMINEN AVAA OVIA}

"Terveys ja sairaus koskettavat meitä jokaista. Ihmisillä on oikeus saada oikeaa tietoa näistä hänelle tärkeistä asioista”, todetaan lääkärien ja toimittajien yhteisessä tiedotussuosituksessa (Tiedotussuositus 2003). Vastikään julkistetun vuoden 2007 Tiedebarometrin mukaan lääketiede on erittäin seurattu tieteenala, jonka kykyyn ratkaista ihmiskunnan isoja ongelmia yhä vankasti luotetaan. 
Tietonsa tieteen saavutuksista suomalaiset saavat joukkotiedotusvälineistä, pääsääntöisesti sähköisistä välineistä (joita $93 \%$ pitää vähintään melko tärkeänä) ja sanomalehdistä (82 \%). Internet ja tietoverkot nousevat yhä suosituimmiksi tietolähteiksi myös terveystiedon haussa; suomalaisista 54 \% pitää niitä vähintään melko tärkeinä (Tiedebarometri 2007, 13-15) .

Mitkä ovat sitten toimittajien omat tietolähteet? Lääketieteen toimittajat ilmoittivat kyselyssä (Järvi, Vuorenkoski ja Vainikainen 2005) tärkeimmiksi tietolähteikseen yksittäiset lääkärit ja tutkijat sekä yliopistot ja tutkimuslaitokset. Kuten suomalaiset yleensä, myös toimittajat luottavat näihin tiedeyhteisön piirissä toimiviin tietolähteisiinsä. Lääkeyritysten tietoon ilmoitti luottavansa vain joka viides toimittaja. Kaikkein epäluotettavimmiksi tiedon lähteiksi nimettiin kuitenkin potilaat. Potilasjärjestötkään eivät ansainneet kovin suuria luottamuspisteitä

Toimittajan kannalta käyttökelpoiset eli "hyvät lähteet" ovat paitsi luotettavia, myös tuotteliaita, mitä Kunelius $(1998,218)$ nimittää institutionaaliseksi takuuksi. Hyvät lähteet omaavat myös auktoriteettia eli niiden asiantuntijat voivat esimerkiksi vedota oppiarvoihinsa. Mikäli auktoriteetin lisäksi tietolähde myös hallitsee nasevan ja ymmärrettävän kielenkäytön, hänestä tulee helposti median paljon käyttämä asiantuntija. Journalisti toimii mielellään tällaisten asiantuntijoiden kanssa, ja yhteistyöstä voi tulla jopa vuosikymmenien mittainen luottamuksellinen vuorovaikutussuhde. Kun journalismi lainaa näiltä instituutioilta niiden tuottaman tiedon sisältöjä, se samalla lainaa rahtusen niiden uskottavuutta (Luostarinen ja Uskali 2004). Luostarinen $(1998,190)$ muistuttaa kuitenkin, että lähdeorganisaatioiden menestyminen julkisuudessa ei riipu yksin suuruudesta tai vallasta. Poliittisesti tai taloudellisesti vähäpätöinen lähde voi olla julkisuuden lemmikki esimerkiksi siksi, että sen asiantuntemusta tai moraalia arvostetaan.

Julkisuuden hallinta määritellään"organisaatioiden tavoitteeksi päästä mediajulkisuuteen ja vaikuttaa siinä myönteiseen näkymiseensä ja julkisuuskuvaansa” (Kuutti 2006, 83). Paitsi perinteisen pr-toiminnan keinoin, julkisuuden hallintaa voidaan toteuttaa myös panostamalla mediaa miellyttäviin aihevalintoihin, näkökulmiin, lähdekäytäntöihin tai julkistamismuotoihin. Koska media on pääsääntöisesti kaupallista toimintaa, uutistuotannon pitää olla tehokasta ja halpaa, mikä osaltaan suosii aktiivista ja osaavaa tiedotustoimintaa. (Ikävalko 1996; Luostarinen 1994).

Julkisuus - mieluiten organisaation itsensä muotoilema julkisuus - on kaikille terveystietoa tuottaville tahoille tärkeää. Jotta organisaation viesti saataisiin mahdollisimman muuttumattomana mediaan, pitäisi sen miellyttää journalistisia käytäntöjä. McQuail (1992) kiteyttää uutisvalinnan kolmeen asiaan: ihmisiin, aikaan ja paikkaan. Viestin mahdollisimman puhtaan läpimenon voisi siis varmistaa se, että tärkeät ihmiset raportoivat tai kommentoivat tärkeiksi miellettyjä asioita tai tapahtumia oikealla hetkellä oikeassa yhteydessä. Tiedottajan ammattirooliin kuuluu olla tietoinen kulloinkin vallitsevista uutiskriteereistä ja erityisesti omaa toimialaa tai yhteisöä koskevista kriteereistä. Pelkkä tiedotteen lähettäminen ei siis vielä riitä takeeksi viestin läpimenosta - ei myöskään ylenpalttinen aktiivisuus, mikä voidaan toimituksissa mieltää painostamiseksi (Juholin \& Kuutti 2003, 89).

Myönteisen mediajulkisuuden arvo piilee paitsi maksuttomuudessa (vrt. mainonnan kalleus), myös siinä, että suuri yleisö pitää journalistista aineistoa 
lähtökohdiltaan mainontaa luotettavampana (Kuutti 2006, 83). Tähän ilmiöön liittyy olennaisesti teoria journalismin strategisista rituaaleista. Niillä tarkoitetaan Gaye Tuchmanin (1972, 660-665) luokittelemia toimintamalleja, joiden avulla journalistit pyrkivät rakentamaan juttunsa niin, että vaikuttavat (näennäisesti) objektiivisilta. Objektiivisuutta voidaan rakentaa esimerkiksi esittämällä keskenään ristiriitaisia ja toisistaan poikkeavia näkemyksiä tasapuolisesti ja ilman toimittajan kannanottoja, jolloin syntyy vaikutelma lähteiden kattavasta valinnasta. Juttuun voidaan myös valita faktoja tukemaan sanottavaa. Kolmas Tuchmanin mainitsema keino on käyttää sitaatteja, jolloin vastuu sanotusta jää lähteelle itselleen.

Terveysjournalismissa tiedon luotettavuuden vaatimukset korostuvat. Lokakuussa 2005 useissa suomalaislehdissä julkaistiin uutisia kahvin myönteisistä terveysvaikutuksista. Jutuissa siteerattiin arvovaltaisena lähdeorganisaationa pidetyn Kansanterveyslaitoksen tutkijoita, jotka esittelivät tutkimuksia kahvin terveyshyödyistä. Yhdessäkään jutussa ei kuitenkaan mainittu juttujen syntyneen tiedotustilaisuudessa, jonka järjestäjä - ja luennoitsijoiden palkkion maksaja - oli Paahtimoyhdistys. Näissä jutuissa Tuchmanin kuvaamat ”journalismin strategiset rituaalit" todella tuottivat objektiivisilta "näyttäviä" uutisia. Voi siis sanoa, että Pahtimoyhdistys onnistui julkisuudenhallinnassaan - journalismin myötävaikutuksella.

Tuchman viittasi omissa tutkimuksissaan myös sosiologi Albert Schutzin ajatukseen, että asioiden "tyypillistäminen" auttaa rutinoimaan maailmaa, jossa elämme. Tyypillistäminen tarkoittaa asioiden käsittelyä tiettyjä asiatyyppejä edustavina tapauksina. Näin toimittajat rakentavat rutiineja pystyäkseen erottelemaan uutisaiheita esimerkiksi "koviksi" ja "pehmeiksi". Arjessa kehittyneet tyypillistykset saavat merkityksensä puitteissa, joita niitä sovelletaan. Tuchmanin mukaan tyypillistykset eivät heijasta sosiaalista todellisuutta, vaan rakentavat sitä"luomalla kontekstin, jossa sosiaalisia ilmiöitä havaitaan ja määritellään" (Tuchman 1973, 117-129). Uutinen ei ole vain uutinen, vaan yksittäiseenkin uutistekstiin sisältyy aina yleisempiä tapoja hahmottaa todellisuutta ja ihmisen paikkaa omassa yhteisössään. Uutisia ja reportaaseja kuullessamme ja lukiessamme meidän on mahdollista vahvistaa käsityksiämme oikeasta ja väärästä, hyvästä ja pahasta sekä ennen kaikkea siitä, mikä on tavallista (Heikkinen, Lehtinen ja Lounela 2005, 258).

Tässä tutkimuksessa tarkennetaan katse viestiin ennen journalistista tuotetta, eli tiedotteeseen. Tiedottajan tavoitehan on saada viesti mahdollisimman muuttumattomana mediaan. Tiedotteen pitää siis vakuuttaa ja suostutella toimittaja hyväksymään tiedotteen sanoma. Retoriikka on vakuuttamisen ja suostuttelun taitoa. Retoriikka on Karvosen (1999, 259) määritelmän mukaan "pyrkimystä antaa haluttu kuva yleisölle asioista tai saada ihmiset näkemään asiat halutussa valossa". Retoriikka voidaan ymmärtää myös argumentaation ja perustelemisen taidoksi. Tässä tutkimuksessa otan lähtökohdaksi KaakkuriKnuuttilan (1998, 233-241) käyttämän "laajan määritelmän”, jossa retoriikan perustana on argumentaatio ja muut retoriset tehokeinot. Retorisen analyysin kohteena ovat teksti ja sen vaikutuskeinot. Tämän tutkimuksen metodinen lähtökohta on analysoida tiedotteissa esiintyvää argumentaatiota. Tarkoitukseni on arvioida ja nimetä tiedotteissa esiintyviä yleisimpiä argumentatiivisia rakenteita, joilla tuotetaan mediaan representaatioita sairastamisesta, potilaan roolista ja asiantuntijuudesta. 


\section{TIEDON LÄHTEILLÄ - PR-TOIMINNAN ARMOILLA?}

Terveystiedon tuottajia on pienessäkin maassa niin paljon, ettei yksittäinen toimittaja ehtisi työpäivänsä aikana edes käydä lukemassa kaikkien organisaatioiden nettisivustoja uutisia etsiessään. Organisaatioilla on kuitenkin tavoitteena saada omista arvoistaan lähtevää julkisuutta. Seuraava kuvio 1 eli terveystiedon tuottajien kehä esittää toimijoita, joilla on keskeinen rooli terveystiedon tuottajina suomalaisessa mediakentässä.

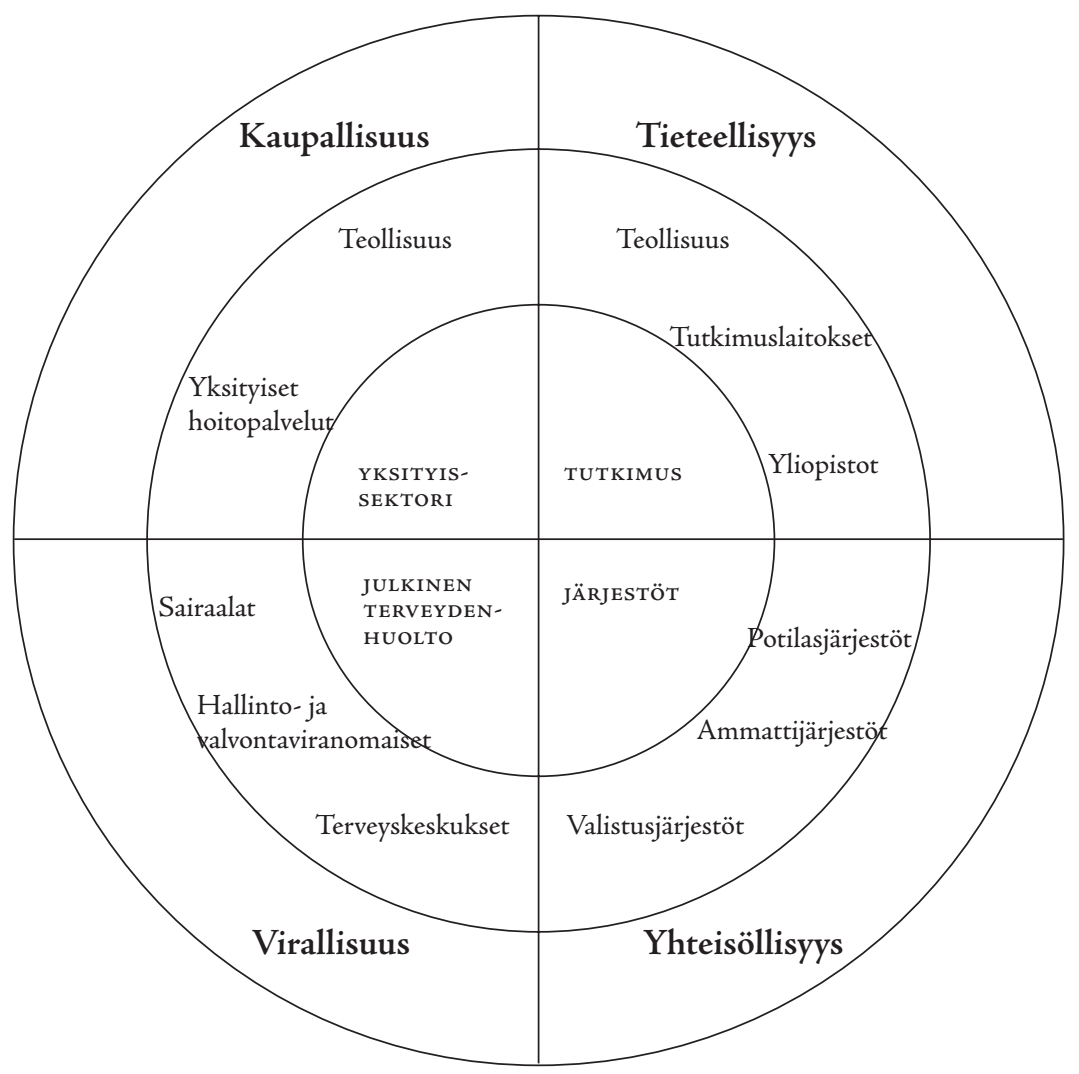

Kuvio 1. Terveystiedon tuottajien kehä

Sisimmällä kehällä ovat tärkeimmät tietoa tuottavat sektorit, jotka olen jakanut neljään kategoriaan: 1) tutkimus, 2) järjestöt, 3) julkinen terveydenhuolto ja 4) yksityinen sektori. Keskimmäisellä kehällä on lueteltu näiden sektoreiden tietoa tuottavia organisaatioita. Tutkimuksen sektorille kuuluvat toimijat ovat yliopistoja ja tutkimuslaitoksia sekä myös yksityisiä yrityksiä, esimerkiksi innovatiivisia läk̈keyrityksiä. Järjestösektorin toimijat ovat niin potilasjärjestöjä kuin esimerkiksi terveydenhuollon ammattiliittoja. Myös lukuisat terveyden edistämiseen keskittyvät valistusjärjestöt tuottavat runsaasti informaatiota. Julkisen terveydenhuollon toimijoista suurimman joukon muodostavat terveyspalveluita tuottavat sairaalat ja terveyskeskukset. Niitä hallinnoivat ja valvovat sekä kuntien terveystoimi että valtion organisaatiot, jotka nekin ovat ahkeria tiedontuottajia. Yksityissektorin toimijoita ovat paitsi yksityiset terveyspalveluntuottajat myös lääkeyritykset ja ja esimerkiksi terveysteknologiayritykset. 
Ulkokehällä on määritetty tiedontuottajatahon viestinnän keskeinen tavoite. Tavoitteet olen määritellyt yleisellä tasolla käyttäen lähteinä yleisesti saatavilla olevia (esim. internet) eri organisaatioiden strategiaohjelmia sekä organisaatioiden tiedottajien haastatteluja (Järvi 2003a). Etenkin julkisen terveydenhuollon organisaatioiden viestintätehtävä on kimurantti; ne haluaisivat olla asiakkaidensa silmissä luotettavia palveluntuottajia ja alan ammattilaisille kiinnostava työnantaja. Toisaalta ne ovat julkishallinnollisia yhteisöjä, joiden päätöksenteon pitäisi olla läpinäkyvää, jolloin esimerkiksi talousvaikeudet tai resurssipula pitäisi saattaa veronmaksajien tietoon (Nordman 2002; Järvi 2003b). Hallinto- ja valvontaviranomaisilla - kuten esimerkiksi ministeriöillä - on niilläkin nykyisin omat viestintästrategiansa, minkä lisäksi niiden tavoittelemaan julkisuuteen vaikuttavat politiikan lainalaisuudet ja ministerivaihdokset. Esimerkiksi vaalien jälkeen tuoreet ministerit pyrkivät ensin profiloitumaan uudistajina, sitten oman työnsä tunnollisina jatkajina.

Yksityisissä yrityksissä taas kaupalliset pyrkimykset taiteilevat - ajoittain jopa taistelevat - tieteellisten pyrkimysten kanssa julkisesta huomiosta. Esimerkiksi uusi lääkemolekyyli on kehittelijöilleen saavutus, jonka he haluaisivat saattaa tiedeyhteisön tietoon. Myös lääkeyrityksen imagon kannalta uudet innovaatiot ovat tärkeitä. Toisaalta liian varhainen uuden keksinnön hehkutus voi ensin nostaa yrityksen pörssikurssia, mutta epäonnistuessaan romahduttaa sen yhdessä yössä (Levi 2000, 50-51).

Järjestöjen viestinnän keskeinen tavoite on sekä olla esillä oman jäsenistön keskuudessa että myös jakaa suurelle yleisölle ja yhteiskunnan päättäjille tietoa sairaudesta. Viestinnästä voi tulla kaksiteräinen miekka: potilasjäseniä olisi hyvä rohkaista elämään mahdollisimman normaalia elämää, mutta poliitikoille pitäisi korostaa taudin vaikeutta, kalleutta ja potilaiden ahdinkoa. Keskeinen tavoite järjestöjen - myös ammattijärjestöjen - viestinnässä on luoda yhteisöllisyyttä jäsenkunnan keskuuteen. Varsinkin ammattijärjestöjen viestinnässä tällä voi olla ratkaiseva rooli esimerkiksi työtaistelujen alla ja aikana.

Yliopistoilla puolestaan on niin sanottu yhteiskunnallisen tehtävänsä mukainen rooli tieteellisen tiedon tuottajana. Tiedemaailman julkisuutta säätelevät omat lainalaisuudet, jotka tuottavat jännitteitä tutkijoiden ja toimittajien suhteisiin. Tieteellinen tutkimus on yleensä hidasta ja tulosten julkaisu edellyttää moninkertaista varmennusta (Väliverronen 2005). Tutkijoiden mielestä uusista havainnoista, hoitomuodoista tai lääkkeistä voi kertoa vasta, kun tutkimustulokset on riittävän luotettavasti varmistettu eli mieluiten julkaistu kansainvälisessä, arvostetussa tiedelehdessä. Toimittajat taas työskentelevät huomattavasti nopeammalla aikajänteellä ja suosivat uusia, ainutlaatuisia, yllättäviä ja usein vasta alustavia tutkimustuloksia sekä ennustuksia tutkimuksen kehityksestä. Toimittajille nämä tieteen hitaan prosessin kautta varmistetut tulokset eivät välttämättä enää ole uutisia (Kauhanen 1997). Väliverronen (emt., 1396) katsoo, että viime vuosina tiede entistä useammin on mukautunut median toimintalogiikkaan. Mediasta on tullut areena, jolla esiintymisellä on vaikutusta yliopistojen ja tutkimuslaitosten imagoon ja sitä kautta niiden sekä yksittäisten tutkijoiden asemaan esimerkiksi tutkimusrahoituksesta kilpailtaessa. Toisaalta kova julkinen paine voi johtaa epävarmojen tutkimustulosten julkistamiseen liian varhaisessa vaiheessa ja pahimmillaan jopa tieteelliseen vilppiin.

Näiden tietoa tuottavien organisaatioiden sisällä toimii vahvoja professioita. Etenkin lääketieteen edustajat katsovat usein, että heidän tehtävänsä on varmis- 
taa oikean tiedon välittyminen kansalaisille (Väliverronen 2005, 1396; Mustajoki 2003). Tämäntapainen valistusajattelu istuu kuitenkin huonosti median toimintalogiikkaan. Journalistin objeiden mukaan toimittajan ei tule toimia minkään yhteiskunnallisen ryhmän äänitorvena.

\section{TAUDIT JA TIEDONTUOTTAJAT JULKISUUSTILAAN PYRKIJÖINÄ}

Viime vuosina on saanut jalansijaa ajatus journalismista julkisuustilana, johon yhteiskunnan taloudelliset, poliittiset ja muut intressitahot pyrkivät (esim. Uskali 2002; Luostarinen 2002; Kunelius 1998). Organisaatioiden tiedottajat tai niiden palkkaamat viestintätoimistot lähettävät toimittajille runsain määrin tiedotteita ja kutsuja tiedotustilaisuuksiin. Tämän tutkimuksen 275 tiedotetta ovat kaikki julkista materiaalia; mukaan ei otettu aineistoja, jotka toimittaja oli saanut käyttöönsä luottamuksellisesti. Mukaan ei otettu myöskään sellaisten tapahtumien tiedotteita, joiden saanti edellytti erityistä akkreditoitumista. Valtakunnallisten ja alueellisten lääkäripäivien puolen sataa tiedotetta eivät sisälly tutkimukseen, jotta ne eivät vääristäisi koko vuoden kokonaiskuvaa. Pois rajattiin myös tutkimuksen kannalta epärelevantit tiedotteet, kuten esimerkiksi tiedotteet sairaalan taidenäyttelyistä tai pikkujoulukutsut. Myös suoranaiset työmarkkinatiedotteet rajattiin pois.

Seuraavassa (taulukko 1) tiedotteiden määrät tiedontuottajatahon mukaan.

Taulukko 1. Tiedotteiden määrät.

\begin{tabular}{|l|l|}
\hline Tiedotteen lähettäjä & $\%$ \\
\hline Yliopistot & 14 \\
\hline Muut tutkimuslaitokset & 9 \\
\hline Lääkeyritykset & 29 \\
\hline Muut yksityiset yritykset & 3 \\
\hline Potilasjärjestöt & 11 \\
\hline Terveydenhuollon muut järjestöt & 9 \\
\hline $\begin{array}{l}\text { Julkinen palvelusektori sekä } \\
\text { hallinto- ja } \\
\text { valvontaviranomaiset }\end{array}$ & 25 \\
\hline Yhteensä & $100 \%$ \\
& $\mathrm{~N}=275$ \\
\hline
\end{tabular}

Lääkeyritykset ovat aktiivisin pr-toiminnan ja viestinnän harjoittaja. Peräti 29 \% tiedotteista tuli lääketeollisuudelta. Julkinen palvelusektori ja viranomaiset tuottivat neljänneksen kaikista tiedotteista. Valtaosa (42 kpl)tähän analyysiin mukaan otetuista viranomaistiedotteista tuli sosiaali- ja terveysministeriöltä. Mukana analyysissa on vain noin neljäsosa ministeriön vuoden 2004 tie- 
dotteista, sillä valtaosa koski sosiaalitoimea tai muita ministeriön hallinnollisia toimia, jotka eivät suoraan liittyneet tutkimuksen aihepiiriin eli sairauden ja terveyden argumentaation rakentamiseen. Tässä tutkimuksessa ei ole mukana sairaanhoitopiirien eikä terveyskeskusten lähettämiä tiedotteita, koska ne olisivat voineet vääristää tulosta. Ovathan palveluorganisaatiot aina hyvin paikallisia, minkä lisäksi isot piirit ja kuntayhtymät ovat yleensä pieniä piirejä aktiviisempia tiedottajia.

Viestintätoimisto tai esimerkiksi yksityinen viestintäpalvelutoiminimi oli mainittu lähettäjäksi yhteensä 47 tiedotteessa. Viestintätoimiston käyttäminen oli yleisintä lääkeyritysten ja muiden yksityisten yritysten lähettämissä tiedotteissa. Mainostoimiston kädenjälki näkyi myös sellaisissa potilasjärjestöjen viestintäkampanjoissa, joissa yksityinen rahoittaja eli yleensä lääkeyritys oli mukana. Yliopistot ja sosiaali- ja terveysministeriö lähettivät tiedotteet pääsääntöisesti omista viestintäyksiköistään.

Selvästi suurin yksittäinen tautiryhmä, josta toimittajille tiedotettiin, olivat syöpätaudit. Syöpää käsitteleviä lehdistötiedotteita tuli lääkeyrityksiltä vuoden aikana yhteensä 13 kappaletta ja saman verran yliopistoilta, tutkimuslaitoksilta ja järjestöiltä. Kaikista tiedotteista siis lähes viisi prosenttia käsitteli syöpää ja syövänhoitoa, mikä kertoo muun muassa siitä, että syövän perustutkimus ja lääkehoidon kehitys on parhaillaan hyvin vilkasta. Lääkeyritysten tiedotteista yli puolet koskikin uusien syöpälääkkeiden Suomeen saatuja myyntilupia, esimerkiksi "Sanofi-aventiksen syöpälä̈̈ke oksaliplatiini on saanut myyntilupaprosessin menestyksekkäästi päätökseen Euroopassa". Vajaa puolet esitteli syöpälääkkeitä koskevia vasta julkistettuja tutkimustuloksia: "Toukokuun Journal of Clinical Oncology -lehdessä julkaistun tutkimuksen mukaan Eli Lillyn pemetreksedi-syöpälä̈ke on osoittautunut tehokkaaksi ja turvalliseksi ei-pienisoluisen keubkosyövän hoidossa." Myös muilta organisaatioilta tulleet tiedotteet käsittelivät pääsääntöisesti tieteellistä tutkimusta, joko perustutkimusta tai esimerkiksi syöpäpotilaiden hoidon taso- tai elämänlaatututkimuksia.

Syöpätutkimusta ja -lääkkeitä argumentoitiin hyvin potilaslähtöisesti ja korostaen uusien hoitomuotojen mullistavaa merkitystä pelätyn taudin hoidossa: "On onnellista, että lymfoomaa voidaan hoitaa nykyään tehokkaasti solunsalpaaja-ja joissakin tapauksissa myös vasta-ainehoidoilla. Runsas puolet lymfoomista voidaan parantaa, erikoislä̈käri L.T. Hyksin syöpätautien osaamiskeskuksesta kertoi." Verrattuna muihin lääkehoitoaiheisiin tiedotteisiin syövänhoitoa argumentoitiin paitsi potilaslähtöisesti, myös kertoen tavallista useammin lääkkeiden sivuvaikutuksista, joista useimmat lääkeyritysten tiedotteet vaikenivat. Tämä voisi johtua esimerkiksi siitä, että syöpälääkkeiden voimakkaat sivuvaikutukset ovat yleisesti tiedossa, joten niitä ei markkinointimielessä tarvitsekaan sivuuttaa. Toisaalta useissa tiedotteissa mainittiin uusien syöpälääkkeiden positiivisena elementtinä verrattuna vanhoihin lääkkeisiin "aiempaa vähäisemmät sivuvaikutukset".

Sydän- ja verisuonitaudit olivat toiseksi suurin tautiryhmä, josta tiedotettiin. Paitsi vilkas lääketutkimus, myös Suomen suurin potilasjärjestö, Sydänliitto, takasivat runsaan tiedontarjonnan. Tiedotteita tästä tautiryhmästä tuli yksityisiltä yrityksiltä kahdeksan kappaletta ja muilta organisaatioilta kymmenen kappaletta, joten niiden osuus oli noin neljä prosenttia. Yritykset keskittyivät uusien lääkkeiden tai hoitotutkimusten esittelyyn, kuten "Suurin läpimurto verisuonitukosten hoidossa 60 vuoteen", potilasjärjestö taas informoi teemaviikoistaan ja tempauksistaan esimerkiksi "Odotettavissa byvää sydämelle - Sydänviikko". Sydän- ja 
verisuonitauteihin liittyvä tiedotustoiminta kasvaa entisestään, kun mukaan otetaan myös kolesteroli- ja statiinilääkeaiheiset tiedotteet. Näitä tuli vuoden aikana lääketeollisuudelta viisi kappaletta ja muilta organisaatioilta kaksi kappaletta.

Myös diabetekseen ja painonhallintaan liittyvä tiedotustoiminta oli vilkasta, samoin aivohalvauksen tunnistamiseen ja hoitoon liittyvistä ongelmista tiedotettiin keskimääräistä enemmän. Tiedotteita tuottivat paitsi lääkeyritykset, ennen kaikkea näitä tauteja sairastavien potilaiden vahvat liitot. Kun vielä otetaan huomioon, että myös reuma-aiheisia tiedotteita oli useita, voidaan todeta Suomessa toimivien potilasjärjestöjen olevan merkittäviä tiedontuottajia.

Myös yksittäiset kampanjat olivat näkyviä. Vuonna 2004 kaksi lääkeyritystä tiedotti markkinoille tulleista ehkäisyrenkaista. Alkuvuodesta tiedotettiin ensin muun muassa ehkäisytutkimuksista, joissa kerrottiin, miten usein naiset unohtavat ottaa ehkäisypillerinsä ja pillerien sivuvaikutuksista. Ehkäisyrenkaasta tuli yhteensä viisi tiedotetta, ja tuotetta esiteltiin toimittajille muun muassa valtakunnallisilla lääkäripäivillä.

Mitkä sairaudet sitten jäivät marginaaliin? Ovatko ne tauteja, joista ei yleisesti kärsitä vai tauteja, joihin ei ollut tarjolla kiinnostavia uusia hoitoja? Psykiatriasta tuli lääkeyrityksiltä yksi tiedote, jossa kerrottiin uuden masennuslääkkeen saamasta myyntiluvasta - USA:ssa. Muilta organisaatioilta tuli yhteensä kymmenen psykiatrisia sairauksia koskevaa tiedotetta. Ne kertoivat joko tuoreesta väitöstutkimuksesta tai esimerkiksi uudesta depression käypä hoito -suosituksesta. Sosiaali- ja terveysministeriön tiedotteita näistä oli kolme, ja ne keskittyivät hoidon järjestämisen ongelmiin. Kuitenkin psykiatriset sairaudet ovat jo ohittaneet muut sairausryhmät esimerkiksi työkyvyttömyyseläkkeiden perusteina. Ovatko mielenterveysongelmat siis edelleen niin tabu tai yhteiskunnan marginaalissa, ettei niistä kertomiseen kannata satsata edes pr-varoja?

Sosiaali- ja terveysministeriön tiedottaminen oli vuonna 2004 hyvin aktiivista. Tämä johtui muun muassa kansallisen terveydenhuollon kehittämisohjelman etenemisestä ja hoitotakuujärjestelmän suunnittelusta. Tiedotteet antavat sekä ministeriön että terveyspalvelujärjestelmän toiminnasta erittäin dynaamisen kuvan, kun ministerit kommentoivat epäkohtia ja ongelmia ratkaistaan hankkeilla ja uudistuksilla.

Medialle tarjotut juttuaiheet noudattelevat Suomessa samaa linjaa, joka havaittiin British Medical Journalin (Bartlett, Sterne ja Egger 2002) analyysissa siitä, mitkä lääketieteen tutkimustulokset siirtyvät brittiläisistä lääketieteen lehdistä, British Medical Journalista (BMJ) ja Lancetista, brittiläisiin sanomalehtiin, Timesiin ja Suniin. Tiedelehdissä oli vuosina 1999-2000 julkaistu eniten alkuperäistutkimuksia, jotka koskivat sydänsairauksia, lapsia, naisia ja syöpää. Sanomalehdet puolestaan poimivat näistä jutuista eniten tutkimuksia, jotka käsittelivät naisia, lisääntymistä, syöpää, lapsia ja sydänsairauksia. Viestinnän kiinnostuksen kohteet näyttävät siis ylikansallisilta. Suomalaisissa tiedotteissa tosin ei lasten sairauksia ja hoitoa juurikaan käsitelty.

\section{AIHEISTA ARGUMENTAATIOON}

Tiedontuottajia ja aiheita koskevan tarkastelun jälkeen tiedotteet on luokiteltu tiedontuottajien kehän (kuvio 1) mukaisesti nelijakoon: 1) yksityiset yritykset, 2) yliopistot ja tutkimuslaitokset, 3) potilas- ja muut terveydenhuollon järjestöt 
sekä 4) hallinto- ja valvontaviranomaiset. Sen pohjalta tässä artikkelissa edetään tiedotteiden argumentoinnin tarkasteluun. Tiedotteista etsitään yhteistä argumentaation tapaa, jolla perustellaan käsiteltävän asian merkitystä ja siten pohjustetaan pääsyä median agendalle.

Analyysin perusteella tiedotteista nousee esille kolme keskeistä argumentaatiotyyppiä: 1) tieteellinen, 2) taloudellinen ja 3) inhimillinen. Niiden pohjalta on rakennettu seuraava tiedotteiden argumentaatiotaulukko (taulukko 2), jossa argumentaatiotyypit (pystysuoraan) on luokiteltu keskeisten tiedontuottajien mukaan (vaakasuoraan). Kukin argumentaatiotyyppi on ensimmäisellä rivillä luonnehdittu yleisluontoisesti sen mukaan, mihin retoriikkaan sen voi tiedotetekstien mukaan nähdä perustuvan. Lisäksi taulukossa on kunkin tiedontuottajatahon tiedotteista kerätty yleisimpiä, lyhyitä esimerkkilauseita tai lauseen osia. Nämä esimerkkilauseet kuvaavat tiedotteissa käytettyjä argumentteja, joilla perustellaan viestin merkittävyyttä. Seuraavissa luvuissa käsitellään yksityiskohtaisemmin kutakin argumentaatiotyyppiä ja niiden pohjalta syntyviä terveyden ja sairauden merkityksiä.

Taulukko 2. Argumentaatiotyypit

\begin{tabular}{|c|c|c|c|}
\hline & Tieteellinen & Taloudellinen & Inhimillinen \\
\hline & $\begin{array}{l}\text { Vetoaa tiedeyhteisön } \\
\text { auktoriteetteihin ja } \\
\text { perustuu tiedeuskon } \\
\text { retoriikkaan }\end{array}$ & $\begin{array}{l}\text { Perustuu taloudellisen } \\
\text { uhan ja hyödyn } \\
\text { retoriikkaan }\end{array}$ & $\begin{array}{l}\text { Perustuu } \\
\text { sairauteen liittyvän } \\
\text { inhimillisen pelon } \\
\text { ja toivon } \\
\text { retoriikkaan }\end{array}$ \\
\hline $\begin{array}{l}\text { Yksityiset } \\
\text { yritykset }\end{array}$ & $\begin{array}{l}\text { Arvostetussa, } \\
\text { lääketieteellisessä } \\
\text { lehdessä julkaistu } \\
\text { tutkimus osoittaa... }\end{array}$ & $\begin{array}{l}\text { Uusi lääke vähentää } \\
\text { komplikaatioita ja sitä } \\
\text { kautta kallista } \\
\text { sairaalahoitoa }\end{array}$ & $\begin{array}{l}\text { Vaiva heikentää } \\
\text { potilaan } \\
\text { elämänlaatua } \\
\text { Lääke antaa } \\
\text { potilaille toivoa } \\
\text { paremmasta } \\
\text { hoidosta }\end{array}$ \\
\hline $\begin{array}{l}\text { Yliopistot ja } \\
\text { tutkimuslaitokset }\end{array}$ & $\begin{array}{l}\text { Tutkimustulos antaa } \\
\text { uutta tietoa taudin } \\
\text { syntymekanismeista } \\
\text { Tulos on julkaistu } \\
\text { kansainvälisessä } \\
\text { arvostetussa } \\
\text { tiedelehdessä }\end{array}$ & $\begin{array}{l}\text { Tutkimuksesta on } \\
\text { mahdollisesti hyötyä } \\
\text { kehitettäessä lääkettä / } \\
\text { hoitoa / laitteita } \\
\text { Suomalaiset tutkijat ovat } \\
\text { osoittaneet... }\end{array}$ & \\
\hline $\begin{array}{l}\text { Hallinto- ja } \\
\text { valvonta- } \\
\text { viranomaiset }\end{array}$ & $\begin{array}{l}\text { Ratkaisu perustuu } \\
\text { tutkimustietoon } \\
\text { Ministeriön tilaama } \\
\text { tutkimus osoittaa... }\end{array}$ & 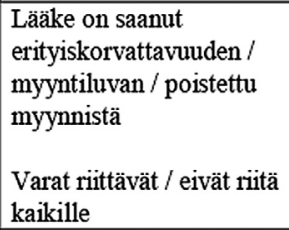 & \\
\hline $\begin{array}{l}\text { Potilas- ja muut } \\
\text { terveydenhuollon } \\
\text { järjestöt }\end{array}$ & $\begin{array}{l}\text { Tutkimus osoittaa, että } \\
\text { taudin esiintyvyys } \\
\text { lisääntyy } \\
\text { räjähdysmäisesti } \\
\text { Suomalaisten potilaiden } \\
\text { parissa tehty tutkimus } \\
\text { osoittaa... }\end{array}$ & $\begin{array}{l}\text { Yhteiskunnalle koituu } \\
\text { huomattavat kustannukset } \\
\text { taudin lisääntymisestä }\end{array}$ & $\begin{array}{l}\text { Ihmiset eivät } \\
\text { tunnista taudin } \\
\text { oireita } \\
\text { Sairaus voi kohdata } \\
\text { kenet tahansa }\end{array}$ \\
\hline
\end{tabular}




\section{TIETEELLINEN ARGUMENTAATIO: TIETEEN KIELESTÄ SUJUVASTI UUTISEKSI?}

"Journalismin perimmäinen eetos tulee sen tietoteoriasta, joka on sukua tieteen tietoteorialle", luonnehtii tiedejournalismia tutkinut Erkki Kauhanen (1998, 291). Molemmat tietoteoriat lähtevät länsimaisen filosofian valtavirralle ominaisesta perusoletuksesta, että on olemassa objektiivisia asiaintiloja tai enemmän totuudellisia ja vähemmän totuudellisia tapoja puhua maailmasta. Tieteen ja tutkimuksen argumentaatio solahtaakin sujuvasti uutiskieleen. Tieteellisen tutkimuksen tavoitteena on muodostaa jotain "uutta" - ja uutuushan on aina uutinen. Tämän voi havaita myös tämän tutkimuksen aineiston analyysissä. Lehdistötiedotteet vilisevät uutuus-terminologiaa: "Uudet aivojen kuvantamismenetelmät tekevät mabdolliseksi tutkia ilmiöitä, joita on aiemmin ollut vaikea lähestyä tieteellisesti." Tiedotteissa esiteltävä tutkimus myös tuottaa erilaisia tuloksia, joita on helppo istuttaa uutiseksi, kuten "Sairaaloiden tuottavuus on alentunut keskimä̈rin 0,7 prosenttia vuodessa vuosina 1998-2000". Varsinkin jos kyse on numeroin ilmaistavista tuloksista, toimittaja saa juttuunsa uutisjournalismin muotokielen mukaista tarkkuutta.

Journalismin uutiskieleen on omaksuttu tieteessä ihannoitu lähestymistapa siitä, miten vanha idea kumoutuu uuden tieltä: "... aiemmin tätä toimenpidettä pidettiin riskialttiina. Viime vuosien uudet tutkimustulokset ovat kuitenkin osoittaneet..." Usein tiedotteeseen ei edes rakenneta selvää ristiriitaa vanhan ja uuden tiedon välille, vaan uskotaan, että lukija ikään kuin annettuna jo tietää vanhan väittämän: "Helsingin yliopistossa valmistuneen väitöstutkimuksen mukaan kasviestrogeenihoito ei lievitä vaihdevuosioireita eikä paranna verisuonisairauksien ennustuksellisia tekijöitä." Joskus tiedotteiden otsikoiden väittämä saa lukijan hämmentymään: "Suomalaisten hammaslä̈äreiden hoitopäätösten tietopohja on byvä."

Tieteelliseen argumentaatioon liittyy myös uhan retoriikkaa. Kuten Kärki (1998) ja Torkkola (2002) ovat todenneet, lääketiede näyttäytyy uutisissa pelottavien sairauksien uhkaa vastaan taistelevana innovatiivisena ja turvaa tuottavana voimana. Uutisissa käytetään toistuvasti uhan, toivon ja hallinnan retoriikkaa. Sairaus on uhka, usein vielä hallitsematon, mutta lääketieteen läpimurrot ja keksinnöt valavat toivoa sairauksien voittamisesta. Hallinnan retoriikka korostaa lääketieteen auktoriteettiasemaa. Aarva ja Lääperi (2005) havaitsivat samanlaista retoriikkaa myös Helsingin Sanomien ja Aamulehden pääkirjoitussivuilla tutkiessaan terveyden edistämistä käsitteleviä kirjoituksia. He muistuttavat, että sodan ja taistelun metaforat juontuvat kauaksi historiaan. Jo edellisen vuosisadan vaihteessa "käytiin taistelua" tuberkuloosia ja muita tartuntatauteja vastaan. Esimerkiksi Syöpäjärjestöjen lehti oli aina 1970-luvun lopulle saakka nimeltään Syöväntorjunta (nykyisin Syöpä-Cancer).

Samaa taistelua käydään tiedontuottajienkin rintamalla. Tiedotteissa viljellään runsaasti uhan retoriikkaa ja taistelun metaforia. "Dramaattiset biv-luvut" tai toteamukset, miten "tilanne on hälyttävä Suomen lähialueilla" jatkavat kertomusta sairaudesta uhasta, joka kohdistuu meihin itsemme ulkopuolelta. Onneksi suomalainen tiedemaailma taistelee tätä uhkaa vastaan. Suomalaisilla onkin Tiedebarometrin (2007) tulosten mukaan vahva luottamus yliopistoihin ja etenkin lääketieteen kykyyn ratkaista ihmiskuntaa uhkaavia ongelmia. Yhtenä syynä tälle tiedeuskolle nähdään juuri yliopistoihin ja tutkijoihin kohdistuva myönteinen mediajulkisuus. Yliopistojen viestintätoimintaa voi siten pitää onnistuneena 
(Tiedebarometri 2007). Myös muut tiedontuottajatahot kuin tiedeyhteisöt argumentoivat tieteen muotokielellä. Ministeriö perustelee hallinnollisia toimiaan "tutkimustuloksin", ja lääkeyritys sijoittaa lääkeinformaationsa ajankohtaan, jossa se voi esitellä kansainvälisessä tiedelehdessä raportoituja lääketutkimuksia.

Yliopiston viestintäyksikössä pyritään yliopiston merkittävyyden ja medianäkyvyyden nostoon, joten ajoittain jo väitöstiedotteissakin luvataan paljon tai annetaan lukijalle valmiiksi pureskeltu tieto tutkimuksen merkityksestä. Yleisin tapa perustella tiedotteessa esitellyn tutkimuksen merkitystä on argumentoida sitä pääsyllä kansainväliseen julkaisuun. Jotta taitamattomampikin ja tiedemaailmaa tuntematon toimittaja ymmärtäisi juuri tuon julkaisun tärkeyden, lehti kuvataan lähes kaikissa tiedotteissa sanoilla "arvostettu kansainvälinen tieteellinen lehti". Mainesanoja ovat myös "yhdysvaltalainen" tai "kaikkein arvostetuin". Tärkeää on myös ilmaista, että ”... artikkeli on julkaistu tänään ilmestyvässä..." Arkikokemus osoittaa, että varsin usein nämä mainesanat myös kelpaavat toimittajille. Tällä tavoin myös toimittaja pystyy perustelemaan, miksi juuri tämä uutinen julkaistiin tässä välineessä juuri tänään.

Tiede on aina nähty myös isänmaallisuuden ja identiteetin vahvistajana. Etenkin Suomen kaltaisessa pienessä maassa tieteellisen tutkimuksen mahdollisimman korkea taso on tärkeä kansallisen itsetuntomme kannalta. Tämä näkyy myös tutkimustiedotteiden argumentaatiossa: "Pitkälti suomalaistutkijoiden voimin on jo aiemmin selvitetty..." Erityisesti tutkimusrahoittajat argumentoivat omissa tiedotteissaan patrioottisen voimakkaasti, jopa hehkuttaen: "Suomen diagnostisen teollisuuden tuotteistamat, yhteistyössä akateemisten tutkimusryhmien kanssa kehitetyt testit, määritysteknologia ja kokonaiset diagnostiset järjestelmät tunnetaan laajasti maailmalla." Tämä Tekesin erään teknologiaohjelman tuloksiin liittyvä tiedoteteksti lähenee jo yrityselämän tuottamien markkinointitiedotteiden fraseologiaa. Joissain tapauksissa julkinen rahoittaja voi mennä suitsutuksessaan jopa mainoskieltä pidemmälle: "Sitrassa iloitsemme Turussa toimivan kohdeyrityksemme onnistumisesta."

Vaikka tiedetiedotteissa keskeinen argumentaatio perustelee tiedon tärkeyttä ja merkitystä uutiskriteereitä kolkuttavalla muodollaan, voi itse asiasisältö olla vaikeaa kieltä. Tieteellistä kieltä ja ilmaisutapaa pidetään yleensä toimittajien keskuudessa vaikeana; etenkin lääketieteilijöitä syytetään "lääkärilatinasta" (Larsson ym. 2003). Tästäkin tiedotemateriaalista löytyy paljon vaikeaa, spesifiä kieltä, joka voi olla omiaan karkottamaan toimittajan viestin ääreltä. Vaikeimmillaan kieli oli väitöstiedotteissa, jotka ovat väittelijöiden itsensä kirjoittamia. Tosin niissä myös yliopiston tiedottajan panoksen huomaa selkeimmin, sillä etenkin otsikoita ja alkulauseita oli selkeästi muutamassa viestintäyksikössä jäntevöitetty. Kun tiedotteen otsikko ja ensimmäinen lause vielä korostavat tulosten yleistä merkitystä, siirrytään tekstin edetessä tieteessä tyypilliseen konditionaalin käyttöön. Etenkin lääkeyritysten tiedotteissa näkyy ammattiviestijän kädenjälki, sillä niissä kieli oli harvoin "liian tieteellistä", vaikka niissä käsiteltiinkin monimutkaisia asioita.

Kauhanen $(1998,310)$ ei kavahda tieteellistä terminologiaa journalismissa eikä kehota sitä erityisemmin välttämään. Päinvastoin hän kehottaa suorastaan tarjoamaan niitä suurelle yleisölle, jotta ihmiset saisivat uusia välineitä ajatteluunsa. Erityisesti lääketieteellisessä informaatiossa vierasperäiset termit on tärkeä selittää ja suomentaa, mutta asianmukaisen terminologian käyttö myös rakentaa siltaa lääketieteilijöiden ja suuren yleisön välille. Potilaan on 
hyvä ymmärtää, mistä hänen lääkärinsä puhuu. Julkinen puhe sairauksista on myös omiaan hälventämään niihin kohdistuvaa pelkoa ja salailua. Tähän tähtäsi muun muassa Syöpäjärjestöjen muutaman vuoden takainen kampanja, jossa trendivaatteiden kuvioinnissa toistettiin syöpä-sanaa.

\section{TALOUDELLINEN ARGUMENTAATIO: SAIRAS KÄY KAIKKIEN KUKKAROLLA}

Jo ennen kuin Sitran yliasiamies Esko Aho vaati "elämäntaparenttuja" kuriin ja maksamaan enemmän "itse aiheutetusta" sairastelustaan (Kauppalehti 31.8.05), on Suomessa käsitelty sairautta paitsi yksilön, myös kansantaloudellisena ongelmana, joka kuluttaa yhteisiä varojamme. Mediassa talousargumentit voivat olla jopa näkyvämpiä kuin vetoaminen ihmisten hyvinvointiin (Aarva \& Lääperi 2005).

Lehdistötiedotteissa taloudelliset argumentit rakentavat taloudellisen uhan ja hyödyn retoriikkaa. Sairaus ja terveydenhoito "rasittavat" kansantaloutta, millä organisaatiot perustelevat omien toimiensa hyödyllisyyttä. Lääkeyhtiöt tuottavat lääkkeitä, jotka säästävät hoitokuluja, yliopistot ja tutkimuslaitokset ratkaisevat kalliiden tautien arvoituksia, ja hallinto-organisaatiot kehittelevät uusia säästökeinoja. Argumentaatioketju on selkeä: "VTT:ltä uusi biotekninen syöpälä̈̈kkeiden tuotantomenetelmä. Edullisempi valmistustapa vähentää kuluttajan ja yhteiskunnan lääkekuluja." Taloudelliset näkökohdat voidaan yhdistää suoraan myös tieteelliseen argumentointiin: "Vihoitteleva vaivaisenluu kannattaa leikata ilman turhaa viivytystä sekä kustannus- että lä̈ketieteellisistä syistä."

Etenkin potilasjärjestöjen tiedotteissa vedotaan yhtä aikaa sekä inhimillisiin että taloudelliseen näkökohtiin: "Jos 10 \% aivoinfarktipotilaista saisi liuotushoidon ja $80 \%$ hoidettaisiin aivohalvausyksikössä, pelastuisi vuosittain 500 potilasta pysyvältä laitoshoidolta tai kuolemalta. 500 potilaan pelastuminen säästäisi 26 miljoonaa euroa." Näin vahvasti numeroin perusteltiin erityisten aivohalvausyksiköiden perustamista Aivohalvaus- ja dysfasialiiton tiedotteessa. Potilasjärjestöt ovat selkeästi yhteiskunnallisia toimijoita, joiden tehtävänä on tietyn ihmisryhmän etujen ajaminen ja julkisen keskustelun herättäminen tietystä sairausryhmästä. Niinpä taloudellinen argumentointi on järjestöjen tiedotteissa yleistä.

Myös lääkeyritykset puhuvat rahasta, eivät yleensä kuitenkaan suoraan lääkkeiden hinnoista, vaan enemmän yhteiskunnalle aiheutuvista lääke- tai hoitokuluista. Koska uudet lääkkeet ovat yleensä vanhempia lääkkeitä kalliimpia, perusteluketju lähtee siitä, että kalleudesta huolimatta uutuuksia käyttämällä säästetään muissa kustannuksissa. Esimerkiksi c-hepatiitin hoitoon käytettävästä tietystä yhdistelmälääkkeestä informoidaan toimittajia: "Tutkimus viittaa selvästi siihen, että genotyyppi 2:ssa ja 3:ssa osalle potilaista saattaisi riittää aiempaa lybyempi eli 3 kuukauden hoitojakso, summaa tuloksia erikoislä̈käri H.N. Hyksin gastroenterologian klinikalta. Lyhempi hoitojakso säästäisi sekä kustannuksia että helpottaisi potilaiden hoitoa." Tyypillistä myös lääkeyritysten tiedotteissa on argumentoida uutta lääkettä hoitojärjestelmä-lähtöisesti. Kuten edellisessä tiedotteessa todettiin, uusi lääke tai hoito on helpompaa "järjestää".

Taloudellisen argumentaation perusta on luonnollisesti suomalainen verorahoitteinen sosiaaliturvajärjestelmä. Etenkin laman jälkeen taloudellinen toimintaympäristömme on ollut rajussa muutoksessa (Mörä 2000, 17-18). Val- 
tiolle ja kunnille kuuluneita toimintoja yksityistetään ja supistetaan. Suojattuja toimialoja avataan vapaalle kilpailulle, ja terveyspalveluyrityksetkin fuusioituvat ja menevät pörssiin. Terveyden- ja sairaanhoidon kulut nousevat voimakkaasti, vaikka niiden osuus bruttokansantuotteesta on yhä OECD-maiden keskitasoa. Tutkimusten mukaan suomalaiset ovat kuitenkin valmiita maksamaan kovia veroja pitääkseen nykyisen terveydenhuollon tason (Alasuutari 1996, 115-120; Kokko \& Telaranta 2006). Tällainen murrosvaihe on omiaan synnyttämään talouteen painottuvaa informaatiota.

Etenkin lääketieteen ammattilaiset esittävät terveysviestintää arvioidessaan usein huolensa medikalisaatiosta, normaaliin arkeen ja ikääntymiseen liittyvien ongelmien lääketieteellistämisestä. Aarva ja Lääperi (2005) kuitenkin havaitsivat, että terveysjulkisuus näyttää pääkirjoituksia lukien pikemminkin ekonomisoituneelta kuin medikalisoituneelta. Talousargumentit olivat näkyvämpiä kuin vetoaminen ihmisen hyvinvointiin. Tämä näkyy selvästi myös tiedotteiden argumentaatiossa. Sairauksille lasketaan hintoja, jotka koituvat yhteiskunnan maksettaviksi. Onkin aiheellista kysyä, miten tämä jo tiedotustoiminnassa tuotettu kuva sairaudesta taloudellisena rasitteena muokkaa toimittajien, median ja sitä kautta suuren yleisön käsitystä sairaista ihmisistä?

\section{INHIMILLINEN ARGUMENTAATIO: HUOLESTU JA PELKÄÄ}

Ihmisyyteen kuuluu tieto omasta kuolevaisuudesta; ihminen pelkää kipua, sairautta ja oman määräysvallan menetystä. Tiedotteiden argumentaatio kumpuaa sairauden pelosta, johon tiede ja terveysteollisuus voivat tuoda uutta toivoa. Terveyttä ja sairautta koskevassa viestinnässä ja mainonnassa liikutaan tällä inhimillisen pelon ja toivon intiimillä reviirillä.

Lainsäädäntömme säätelee erittäin tarkasti terveyspalveluita ja lääkkeitä koskevaa mainontaa, vaikka se kuuluukin yksityisen yritystoiminnan piiriin. Reseptilääkkeitä ei EU:n alueella saa mainostaa suurelle yleisölle, mutta sairauksien hoidosta voi informoida. Suomessa toimivien lääkeyritysten internetsivut ovat laajentuneet ja monipuolistuneet aivan viime vuosina. Myös lääketieteen toimittajien piirissä on useaan kertaan todettu pr-toiminnan voimistuminen (Suomen Lä̈̈kärilehti 2002, 57:27-29, 2874-2875). Internetin potilassivustojen ja prtoiminnan lisäksi myös suorat kontaktit potilaisiin ovat lisääntyneet. Potilasjärjestöjen ja muiden tahojen pitämissä, mutta lääketeollisuuden sponsoroimissa yleisötilaisuuksissa kerrotaan sairauden lisäksi myös siihen tarkoitetuista uusista lääkehoidoista. Kelan tutkimusprofessori Timo Klaukka (LSV-tiedote 2001) on luonnehtinut tätä informaatiota liian kritiikittömäksi ja käyttänyt menettelytavasta termiä "tiedon pesu". Ottamalla välikädeksi potilasjärjestö tai media - tiedon alkuperä voidaan Klaukan mukaan häivyttää ja kiertää näin markkinointisyytökset. Onko liian kerettiläistä kysyä, miksi lääketeollisuuden ja kansalaisten suora kontakti pitäisi kieltää?

Markkinointia saa kohdistaa vain tietyille terveydenhuollon ammattihenkilöille, lähinnä lääkäreille ja proviisoreille. Joskus voikin käydä niin, että markkinointiin tarkoitetut väittämät ja ilmaukset siirtyvät huomaamatta myös kuluttajaviestintään: "Rosuvastatiinin teho on nyt osoitettu suurella määrällä suomalaisia potilaita. Tavoitetasolle pä̈̈seminen heti aloitusannoksella on erittäin tärkeää, sillä se tarkoittaa, että yhä harvempien potilaiden lä̈keannosta tarvitsee suurentaa. Tämä 
on byvä uutinen sekä potilaille että lä̈käreille, sanoo DISCOVERY-tutkimuksen Suomen osuudesta vastannut dosentti T.S." Potilaiden ei periaatteessa tarvitsisi olla huolissaan lääkäreistä, mutta lääkkeitä argumentoidaan tiedotteissakin usein lääkäri-lähtöisesti: "Suomalaisten korkeat kolesterolitasot buolestuttavat lääkäreitä. Korkean kolesterolin hoitoon, suomalaisten potilaiden ja läk̈äreiden käyttöön on saatu ns. kaksoisestohoito, statiini ybdistettynä etsetimibiin." Tiedote vihjaa, että kansalaisten tulisi olla huolissaan kolesterolistaan, sillä lääkäritkin ovat.

Luostarinen (2002) on todennut modernin journalismin syntyneen aikana, jolloin tiedon tuotantoa, oikeutusta ja jakelua koskevat uskomukset olivat vielä suhteellisen vakaita. Sata vuotta sitten tietoa tuottivat asiantuntevat eliitit (tutkijat, juristit, lääkärit, byrokraatit jne.). Tieto sai oikeutuksensa noiden eliittien kirjaamista tiedon tuottamisen säännöistä (esim. tieteelliset menetelmät, lääketieteen hoito-ohjeet). Tietoa jaettiin ylhäältä alaspäin, ja yhteiskunnallista elämää jäsensi voimakkaasti perheen metafora, jossa kansalaiset olivat lasten lailla kasvatuksen ja sivistyksen kohteena (emt. 23). Inhimillinen argumentaatiotyyppi saa tiedotteissa usein alamaisuuteen tai suoranaiseen holhottavuuteen liittyviä sävyjä. Sairaus on ihmisessä, mutta häntä puhutellaan kuin lasta tai sairaalan potilasta, mikä korostuu muun muassa me-muodon runsaana viljelemisenä: "Potilaiden ja heidän läheistensä elämänlaatu paranisi huomattavasti, jos voisimme pitää nämä oireet mahdollisimman pitkään poissa taudinkuvasta."

Potilasjärjestöjen rooli on paitsi toimia potilaiden etujärjestönä, myös rakentaa yhteisöllisyyden ja tuen tunnetta jäseniensä kesken. Onkin luontevaa, että järjestöjen viestinnästä löytyy runsaasti inhimillistä argumentaatiota. Voi kuitenkin pohtia, pitääkö sairauksiin liittää niin vahvaa uhan ja pelon retoriikkaa kuin tutkimuksen tiedotteista havaittiin. Tämä kysymys herää etenkin silloin, kun potilasjärjestö harjoittaa lääke- tai elintarvikeyrityksen kanssa viestinnällistä yhteistyötä. Joissakin tiedotteissa yhteistyökuvio on selvästi ilmaistu: "Koska kohonnut kolesteroli ei näy eikä tunnu, ibmiset eivät aina osaa bakeutua boitoon. Sydänliitto tekee tärkeää valistustyötä, jossa Pfizer haluaa olla mukana. Nyt julkaistava CD on osa Pfizerin ybteistyötä terveysvalistuksen saralla." Mukana oli kuitenkin myös tiedotteita, joissa yhteistyökuvio ei käynyt yhtä selvästi ilmi.

Tällainen potilasjärjestöön "liittyminen" on yrityksille selkeästi imagonrakentamista toimittajien ja suuren yleisön suuntaan. On kuitenkin vaikea uskoa, että kukaan toimittaja kehaisisi jutussaan, miten hienoa työtä Pfizer tekeekään tukiessaan Sydänliiton terveysvalistusta. Pikemminkin nykyisessä mielipideilmastossa toimittaja saattaisi tehdä ilkeäsävyisen jutun kaupallisuuden tunkeutumisesta yleishyvää mainettaan vaalivaan järjestöön. Kuten Ikävalko (1996) toteaa, organisaation saamaan julkisuuteen vaikuttavat myös yhteiskunnassa kulloinkin vaikuttavat ajatussuunnat, trendit ja teemat. Myös mediatrendit luovat puitteita kulloinkin vallitseville kriteereille ja arvostuksille. 2000-luvulla lääketeollisuus on pudonnut takavuosien jalustaltaan hyväntekijänä (Juvonen 2006) ja saanut kielteistä julkisuutta enemmänkin rahantekijänä. Lääkkeidenkehittäjän imago on julkisuudessa kahtalainen; toisaalta ihaillaan syövän paranevia hoitotuloksia, toisaalta paheksutaan esimerkiksi kolesterolilääkkeiden "tuputtamista terveille".

Yritykset saattoivat myös ajoittaa oman tiedotuskampanjansa potilasjärjestöjen teemaviikkojen tai -päivien yhteyteen ja päästä näin ikään kuin osalliseksi sairauteen liittyvästä yhteisöllisyydestä. Eräs yritys esimerkiksi tarjosi Maailman tupakattomaan päivään liittyen haastatteluun valmistautuneiden asiantuntijalääkäreiden ja tupakoinnin lopettaneiden ihmisten yhteystietoja. On tavallista, 
että yritysten tiedotteissa tarjotaan haastateltaviksi lääketieteen asiantuntijoiden lisäksi myös "taviksia". He ovat potilaita, jotka on rekrytoitu "todistamaan" aiheena olevan taudin vaikeudesta ja saatavilla olevan hoidon tuloksellisuudesta. Näin pr-toiminta pyrkii saamaan mediavälitteiseen viestiinsä inhimillistä koskettavuutta ja siten mukautumaan nykyjournalismin yksilöllistymiseen. Yksilöllistymisellä tarkoitetaan abstraktien asioiden kertomiseen yksilöiden kautta. On aivan mahdollista, että tähän kiireisessä uutistyössä myös tartutaan.

On merkille pantavaa, että yliopistojen ja tutkimuslaitosten sekä hallinto- ja valvontaviranomaisten tiedotteissa inhimillinen argumentaatiotyyppi ei näyttäydy lainkaan. Ainakaan vuoden 2004 tiedotteista sitä ei tässä analyysissä havaittu. On mahdollista, että kyse on luennan puutteista tai taitamattomuudesta, mutta silloinkin se tarkoittaa, ettei inhimillinen argumentaatiotyyppi ole ainakaan yhtä silmiinpistävä kuin tieteellinen ja taloudellinen argumentaatio. Tämän ilmiön taakse pääsee tuskin pureutumaan muutoin kuin haastattelemalla kyseisten organisaatioiden asiantuntijoita ja tiedottajia. Tämä olisikin tärkeä jatkotutkimuksen aihe. Terveysjournalismin tutkimuksessa on jo pitkään kiinnitetty huomiota aktiivisen potilaan roolin sivuuttamiseen. On kuitenkin mahdoton sanoa, rakennetaanko tätä kuvaa jo yritysten pr-toiminnassa ja organisaatioviestinnässä vai pyritäänkö tiedotteissa vain miellyttämään havaittuja journalistisia käytäntöjä.

\section{LOPUKSI: KATOAAKO AKTIIVINEN KANSALAINEN TIETOVERKKOON?}

Terveysviestintää tuottaville organisaatioille on tyypillistä oman toiminnan merkityksen korostaminen, mikä näkyy tiedotteiden argumentaatiossa. Yritykset tuottavat ihmishenkiä pelastavia lääkkeitä ja palveluita, yliopistojen tiedotus keskittyy omien tutkijoiden saavutuksiin, ja viranomaisorganisaatiot tuottavat palveluita ja järjestelmää "hallintoalamaisille". Missä kuuluu kansalaisen oma ääni? Potilas- ja valistusjärjestöt voisivat olla taho, jonka "kuuluisi" vahvistaa julkista kuvaa aktiivisesta kansalaisesta. Niiden viestin pääpaino on kuitenkin taloudellisessa argumentaatiossa sairaudesta, joka käy kalliiksi ja tuottaa merkittäviä haittoja. Inhimillinen argumentaatio keskittyy sairauteen, joka uhkaa ihmisen hyvinvointia salakavalasti. Koska järjestölle on hyödyllistä julkisuudessa perustella omaa tarpeellisuuttaan niin kansalaisille, poliitikoille kuin rahoittajille, viestintä keskittyy painottamaan järjestön omaa roolia ongelmien ratkaisijana.

Yleisin kritiikki, jonka lääketieteen ammattilaiset liittävät sairauksia ja niiden hoitoa koskevaan mediajulkisuuteen, on huoli medikalisaatiosta, normaalien elämänilmiöiden lääketieteellistymisestä. Useat lääkärit (esim. Mustajoki 2003; Vesikari \& Kortelainen 2005) ovat ilmaisseet huolensa siitä, että uudet ja sensaatiomaiset terveyteen liittyvät aiheet saavat helposti kohtuuttomasti julkisuutta, mikä muokkaa ihmisten käsitystä terveydestä ja sairaudesta. Pertti Mustajoki - joka on itse ahkera julkinen keskustelija - vetoaa lääkärikollegoihinsa haitallisen medikalisaation lietsomisen riskeistä (emt. 2003). Vetoaminen lienee aiheellista, vaikka ehkä tuloksetonta, niin sankoin joukoin lääkärit lehdistötiedotteissa esiintyvät. Vaikka yritykset maksavat näille kommentoiville lääkäreille, kaikki lääkärit eivät silti suostu yksiselitteisesti kehumaan yrityksen valmistetta. Kutsun "häivyttämiseksi" tekniikkaa, jolla asiantuntija saadaan 
viestiin mukaan, vaikka hän ei suoranaisesti argumentoi valmisteen puolesta. Tiedotteessa saatetaan ensin kehua yrityksen uutta lääkettä, minkä jälkeen nimeltä mainittu lääkäri toteaa jotain ympäripyöreää hoidon haasteista. Tästä voi syntyä käsitys, että asiantuntija pitää tätä tekstissä aiemmin kehuttua valmistetta tärkeänä. Tarkempi lukeminen paljastaa, että asiantuntija ei varsinaisesti edes kommentoinut lääkettä.

Journalististen käytäntöjen miellyttäminen voi siis mennä niin pitkälle, että yleisesti arvostetun lääkäriprofession edustajan pelkkä nimi riittää tuomaan tiedotteeseen toivottua arvovaltaa. Auktoriteetilta haetaan vankennusta argumentaatioon. Onhan median omienkin tavoitteiden kannalta tärkeää, että jutuissa esiintyvä lähde on ennen muuta uskottava (Nieminen \& Pantti 2004). Lääkäreitä on journalistisissa käytänteissä perinteisesti pidetty luotettavina asiantuntijoina kaikissa terveyttä ja sairautta koskevissa kysymyksissä. Viimeaikaisessa terveysjournalismin tutkimuksessa (Torkkola 2001; Torkkola 2002) on kuitenkin kritisoitu sitä, että terveyden määrittelyn jättäminen yksin lääketieteen tai terveydenhuollon ammattilaisille jättää vain vähän tilaa kansalaisten omille määrittelyille. Toki myös pr-toiminnassa on sijaa potilaiden kertomuksille. Tiedotustilaisuuksissa on varsin usein mukana potilaita, antamassa sairaudelle kasvot. Torkkola (2002) kuitenkin katsoo, että kansalaisten pitäisi päästä esittämään näkemyksiään terveydestä ja sairaudesta muutoinkin kuin vain esittämällä oman intiimin sairauskertomuksensa medialle. Aktiivisimmat kansalaiset kohtaamme, kun luemme onnistuneista laihduttajista, katselemme televisiosta elämää pelissä ja hurraamme mainoskanavan suurimmalle pudottajalle. Vaikka tämän tyyppinen terveyden edistämiseen kannustava journalismi rakentuu usein terveyden asiantuntijoiden tiedoille ja opastukselle, siinä sentään kuuluu kansalaisen oma ääni - sieltä kuntosalin nurkasta.

Mistä sitten löytyisi toimittajan luotetuksi kumppaniksi tiedontuottaja,jonka luonteva rooli olisi tuoda esiin aktiivista, itsestään huolehtivaa ja sairastuessaankin oikeuksistaan tietoista kansalaista? Ainakin tämän tutkimuksen mukaan potilasjärjestöille tämä rooli tuottaa selvästi vaikeuksia eikä se muiden tiedontuottajien harteille luontevasti istu. Vilkkaimmillaan tätä aktiivista kansalaiskeskustelua käydään internetin keskustelusivustoilla, joilla toisensa kohtaavat niin vauvojen vanhemmat, huumeongelmaiset, laihduttajat kuin syöpäpotilaatkin. Tietoa tuottavien instituutioiden vaikutusvallan kannalta ongelmallista on se, että tällä "tiedon valtatiellä" ovat tieto, tiede ja henkilökohtaiset kokemukset näennäisesti samanarvoisia.

Journalismille tulevaisuus merkitsee haasteita, vaikka uusi Tiedebarometri (2007) kertoo kansalaisten luottamuksen joukkotiedotusvälineisiin kasvaneen ja ihmisten toivovan mediaan yhä lisää tiedejuttuja. Internetin vaikutusvalta kuitenkin kasvaa voimakkaasti. Tiedebarometri paljasti internetin olevan tiedetiedon lähteenä erittäin tai melko tärkeä jo 54 prosentille suomalaisista, kun luku kolme vuotta sitten oli vielä 44 prosenttia. Ei olekaan ihme, että niin lääkeyritykset, potilasjärjestöt kuin viranomaiset rakentavat vauhdilla omia terveysaiheisia internetsivustojaan. On mielenkiintoista nähdä, mitä käsityksellemme sairauksista, potilaan roolista ja lääkäriprofession auktoriteetista tapahtuu internetin roolin yhä kasvaessa. 
Aarva, Pauliina \& Pirjo Lääperi (2005) Terveysretoriikka pääkirjoituksissa. Helsingin Sanomien ja Aamulehden välittämä kuva terveyden edistämisestä vuosina 2002-2003. Duodecim 121:1, 71-78.

Alasuutari, Pertti (1996) Toinen tasavalta. Suomi 1946-1994. Jyväskylä: Vastapaino, 2006.

Bartlett, Christopher \& Jonathan Sterne \& Matthias Egger (2002) What is newsworthy? Longitudinal study of the reporting of medical research in two British newspapers. British Medical Journal 2002;325:81

Heikkinen, Vesa \& Outi Lehtinen \& MikkoLounela (2005) Lappeenrantalaismies löi toista nenään baarissa. Uutisia ja uutisia. Teoksessa Vesa Heikkinen: Tekstien arki. Tutkimusmatkoja jokapäiväisiin merkityksiimme. Tampere: Gaudeamus.

Journalistin ohjeet. Suomen Journalistiliitto.

Juholin, Elisa \& Heikki Kuutti (2003) Mediapeli - anatomia ja keinot. Hämeenlinna: Inforviestintä, 2003.

Ikävalko, Elina (1996) Organisaatiot julkisuuden pelikentillä. Teoksessaः Risto Uimonen \& Elina Ikävalko (1996) Mielikuvien maailma. Miten mediajulkisuutta muokataan ja imagoja rakennetaan? Jyväskylä: Inforviestintä, 1996.

Juvonen, Hannu (2006) Osataanko talouden ja liikeyritysten etiikasta puhua? Kirjallisuusarvostelu. Suomen Lääkärilehti 61:42, 5389.

Järvi, Ulla (2003a) Potilas ja Media. Potilaan rooli terveysjournalismin eri lajityypeissä. Pro gradu -tutkielma. Jyväskylän yliopisto, Viestintätieteiden laitos.

Järvi, Ulla (2003b) Suomi sairastui kun HUS sairastui. Journalismin kritiikin vuosikirja 2003, Tiedotustutkimus 26:1, 26-35.

Järvi, Ulla \& Lauri Vuorenkoski \& Tuula Vainikainen (2005) Toimittaja taiteilee lääkeviestinnän ristiaallokossa. Kysely lääketieteen toimittajien näkemyksistä lääketiedon tuottajista ja tiedon luotettavuudesta. Tiedotustutkimus 28:4-5, 103-113.

Kaakkuri-Knuuttila Marja-Liisa (toim.) (1998) Argumentti ja kritiikki. Lukemisen, keskustelun ja vakuuttamisen taidot. Tampere: Gaudeamus, 1998.

Karvonen, Erkki (1999) Elämää mielikuvayhteiskunnassa. Imago ja maine menestystekijöinä myöhäisteollisessa yhteiskunnassa. Tampere: Gaudeamus, 1999.

Kauhanen, Erkki (1998) Ajatuksia tiedejournalismin tekemisestä. Teoksessa Anu Kantola ja Tuomo Mörä: Journalismia! Journalismia? Juva: WSOY. 291-316.

Kokko, Simo \& Tauno Telaranta (2006) Perusterveydenhuollon tila 2006. Suomen Lääkärilehti 61:49-50, 521-5218.

Kunelius, Risto (1998) Modernin myyntitykit. Journalistisen professionaalisuuden pulmat ja haasteet. Teoksessa Ullamaija Kivikuru \& Risto Kunelius (toim.): Viestinnän jäljillä. Näkökulmia uuden ajan ilmiöön. Juva: WSOY. 207-230.

Kunelius, Risto (2003) Viestinnän vallassa. Johdatus joukkoviestinnän kysymyksiin. Porvoo: WSOY, 2003.

Kuutti, Heikki (2006) Uusi mediasanasto. Jyväskylä: Atena, 2006.

Kärki, Riitta (1998) Lääketiede julkisuudessa. Tampere: Vastapaino, 1998.

Larsson, Anna \& Andrew D. Oxman \& Cheryl Carling \& Jeph Herrin (2003) Medical messages in the media - barriers and solutions to improving medical journalism. Health Expectations 2003;6:323-331.

Levi, Ragnar (2000) Medical Journalism. Exposing Fact, Fiction, Fraud. Lund: Studentlitteratur, 2000.

Luostarinen, Heikki (1994) Mielen kersantit. Julkisuuden hallinta ja journalistiset vastastrategiat sotilaallisissa konflikteissa. Hanki ja jää. Helsinki, 1994.

Luostarinen, Heikki (1998) Vahvojen asialla? Julkisuuden hallinnan mekanismi ja journalistinen itsenäisyys. Teoksessa: Ullamaija Kivikuru \& Risto Kunelius (toim.), Viestinnän jäljillä. Näkökulmia uuden ajan ilmiöön, Helsinki (Juva): WSOY. 189-206.

Luostarinen, Heikki (2002) Moneksi muuttuva journalismi. Teoksessa Touko Perko \& Raimo Salokangas \& Heikki Luostarinen (toim.) Median varjossa. Jyväskylä: Mediainstituutti, 2002. $22-29$.

Luostarinen, Heikki \& Turo Uskali (2004) Suomalainen journalismi ja yhteiskunnan muutos 1980-2000. Raportissa: Artikkelikokoelma tutkimushankkeesta Sosiaaliset innovaatiot, yhteiskunnan uudistumiskyky ja taloudellinen menestys. Helsinki: Sitra, 2004. 
Lääkärien ja toimittajien yhteinen tiedotussuositus (2003) Suomen Lääkäriliitto ja Suomen Journalistiliitto. http://www.laakariliitto.fi/etiikka/liiton_ohjeet/tiedotussuositus1.html.

McQuail, Denis (1992) Media Performance. Mass Communication and The Public Interest. Sage Publications, Great Britain, 1992.

Mustajoki, Pertti (2003) Lääkäri ja medikalisaatio. Duodecim 119:19, 1869.

Mörä, Tuomo (2000) Konsensuksen taakka. Teoksessa Pekka Aula \& Salli Hakala (toim.): Kolmet kasvot. Helsinki: Loki-kirjat, 2000. 17-26.

Nieminen, Hannu \& Mervi Pantti (2004) Media markkinoilla. Johdatus joukkoviestintään ja sen tutkimukseen. Helsinki: Loki-kirjat, 2004.

Nordman, Tarja (2002) Viestintä terveydenhuollon organisaatiossa. Teoksessa Sinikka Torkkola (toim.): Terveysviestintä. Vammala: Tammi, 2002. 121-149.

Suhonen, Pertti (2007) Suomalaisten eriytyvät ja muuttuvat arvot. Teoksessa Sami Borg $\&$ Kimmo Ketola \& Kimmo Kääriäinen \& Kati Niemelä ja Pertti Suhonen: Uskonto, arvot ja instituutiot. Suomalaiset World Values -tutkimuksissa 1981-2005. Tampere: Yhteiskuntatieteellisen tietoarkiston julkaisuja 4, 2007. 26-46.

Suomen Lääkärilehti (2002) Lääketieteen toimittajat etsivät ja kyselevät. Tiede ja tutkimus ovat toistaiseksi totta. SLL 57:27-29, 2874-2875.

Tiedebarometri 2007 (2007) Tutkimus suomalaisten suhtautumisesta tieteeseen ja tieteellistekniseen kehitykseen. Tieteen tiedotus ry. Helsinki: Yliopistopaino.

Torkkola, Sinikka (2001) Potilaan paikkaa etsimässä. Journalismikritiikin vuosikirja, Tiedotustutkimus 24:1, 107-108.

Torkkola, Sinikka (2002) Journalistista terveyttä - Näkökulmia terveysjournalismiin. Teoksessa Torkkola, Sinikka (toim.) Terveysviestintä. Vammala: Tammi, 2002.71-88.

Tuchman, Gaye (1972) Objectivity as a Strategic Ritual. American Journal of Sociology, 77:4, 660-679.

Tuchman, Gaye (1973) Making News by Doing Work: Routinizing the Unexpected. American Journal of Sociology, 79:1, 110-103.

Uskali, Turo (2002) Kriittisyys - nykyjournalismin selkäranka. Viisi käytännön neuvoa hyvän journalismin lisäämiseksi. Teoksessa Touko Perko \& Raimo Salokangas \& Heikki Luostarinen (toim.): Median varjossa. Jyväskylä: Mediainstituutti, 2002. 30-47.

Vesikari, Timo \& Kati Kortelainen (2005) MPR-rokotus ja autismi. Mediakohun vaikutus rokotuskattavuuteen Englannissa, Ruotsissa ja Suomessa. Duodecim 121:20, 2487-2490.

Väliverronen, Esa (2005) Lääketiede mediassa. Duodecim 121:13, 1394-1398. 